\title{
Modifiable risk factors associated with bone deficits in childhood cancer survivors
}

\author{
Lynda E Polgreen ${ }^{1,7^{*}}$, Anna Petryk ${ }^{1,7^{*}}$, Andrew C Dietz ${ }^{2}$, Alan R Sinaiko ${ }^{1}$, Wendy Leisenring ${ }^{3}$, Pam Goodman ${ }^{3}$, \\ Lyn M Steffen ${ }^{4}$, Joanna L Perkins ${ }^{5}$, Donald R Dengel ${ }^{6}$, K Scott Baker $^{3}$ and Julia Steinberger ${ }^{1}$
}

\begin{abstract}
Background: To determine the prevalence and severity of bone deficits in a cohort of childhood cancer survivors (CCS) compared to a healthy sibling control group, and the modifiable factors associated with bone deficits in CCS.

Methods: Cross-sectional study of bone health in 319 CCS and 208 healthy sibling controls. Bone mineral density (BMD) was measured by dual-energy x-ray absorptiometry (DXA). Generalized estimating equations were used to compare measures between CCS and controls. Among CCS, multivariable logistic regression was used to evaluate odds ratios for BMD Z-score $\leq-1$.

Results: All subjects were younger than 18 years of age. Average time since treatment was 10.1 years (range 4.3 17.8 years). CCS were 3.3 times more likely to have whole body BMD Z-score $\leq-1$ than controls $(95 \% \mathrm{Cl}: 1.4-7.8 ; \mathrm{p}$ $=0.007$ ) and 1.7 times more likely to have lumbar spine BMD Z-score $\leq-1$ than controls (95\% Cl: 1.0-2.7; $p=0.03$ ). Among CCS, hypogonadism, lower lean body mass, higher daily television/computer screen time, lower physical activity, and higher inflammatory marker IL-6, increased the odds of having a BMD Z-score $\leq-1$.
\end{abstract}

Conclusions: CCS, less than 18 years of age, have bone deficits compared to a healthy control group. Sedentary lifestyle and inflammation may play a role in bone deficits in CCS. Counseling CCS and their caretakers on decreasing television/computer screen time and increasing activity may improve bone health.

\section{Introduction}

Osteoporosis is a systemic skeletal disease characterized by low bone mass and microarchitectural deterioration, resulting in an increased susceptibility to fracture [1]. Reduced bone mineral density (BMD) is a recognized condition among childhood cancer survivors (CCS). It is estimated that up to $46 \%$ of CCS less than 18 years old have reduced BMD [2-8]. Although children usually recover from fractures without any complication, fractures in adults have been shown to significantly increase both morbidity and mortality $[9,10]$. Importantly, the majority of bone accretion occurs in adolescence and young adulthood with peak bone mass reached by the second or third decade [11]. Treatment during adolescence interrupts this critical period of bone acquisition. A resultant decrease in peak bone mass would be

\footnotetext{
*Correspondence: polgr001@umn.edu; petry005@umn.edu

${ }^{1}$ Department of Pediatrics, University of Minnesota, Minneapolis, MN, USA

Full list of author information is available at the end of the article
}

expected to increase the risk of osteoporosis and osteoporotic fractures later in life [12].

The known risk factors for reduced BMD in CCS include treatment with glucocorticoids [6,13-16], radiation [16-21], methotrexate $[2,6,16,18,21]$, and endocrine insufficiencies such as growth hormone $(\mathrm{GH})$ deficiency $[5,17,22]$ and hypogonadism $[6,17,23]$ that are sequelae of cancer treatment. While efforts are made to limit the exposure to these agents without compromising their effectiveness, there are limitations to these approaches due to the nature of the disease and available treatment options. Hence, there is a need to identify modifiable risk factors to design appropriate preventive and therapeutic interventions during childhood and adolescence while there is still potential for BMD gain. Currently there are limited data on modifiable lifestyle factors that could influence bone health in CCS, therefore we undertook a study to evaluate the associations between potentially modifiable factors and bone deficits in CCS. We hypothesized that CCS will have lower BMD compared to the sibling control group and that low activity, low lean body
C Biomed Central

(c) 2012 Polgreen et al; licensee BioMed Central Ltd. This is an Open Access article distributed under the terms of the Creative Commons Attribution License (http://creativecommons.org/licenses/by/2.0), which permits unrestricted use, distribution, and reproduction in any medium, provided the original work is properly cited. 
mass, high percent body fat, higher levels of markers of inflammation, and lower dietary calcium, vitamin D and zinc intake will be associated with bone deficits in CCS. These data could be used to focus bone health promoting interventions and by pediatricians during routine health maintenance visits to guide counseling of CCS on ways to improve bone health, prevent osteoporosis and reduce the risk of fractures.

\section{Methods}

The study was approved by the Institutional Review Board: Human Subjects Committee at the University of Minnesota Medical Center and Children's Hospitals and Clinics of Minnesota. Consent (and assent as appropriate) was obtained from children and their parent/guardian(s). We identified 723 living subjects, ages 9-18 years old, treated for cancer at the University of Minnesota Amplatz Children's Hospital and the Children's Hospitals \& Clinics of Minnesota, in remission and surviving for $\geq$ 5 years after diagnosis of leukemia, central nervous system (CNS) tumors and solid tumors. Of these, 66 were not able to be contacted; of the remaining 657, 319 (49\%) agreed to participate. 110 had leukemia, 127 solid tumors (i.e. sarcoma, renal, neuroblastoma, non-Hodgkin's lymphoma), and $82 \mathrm{CNS}$ tumors (i.e. glial tumors, retinoblastoma, neuroectodermal tumors). 134 had a history of corticosteroid treatment, and 74 had a history of treatment with radiation (31 cranial radiation). Participants treated with hematopoietic cell transplantation (HCT) were excluded. There were no significant differences in age, sex, race, diagnosis, age at diagnosis and length of follow-up (time from diagnosis to study evaluation) between CCS participants and non-participants. A contemporary control group of 208 healthy siblings of CCS were recruited. Controls known to suffer from chronic illnesses including hypothyroidism and delayed puberty, or at risk for GH deficiency (i.e. height $>2$ standard deviation (SD) below the mean and height velocity $>2$ SD below the mean) were excluded from participation.

Following a 10-12 hour overnight fast, all participants underwent a physical examination (including Tanner staging [24] by a trained study physician), height measured by wall mounted stadiometer (without shoes) to the nearest $0.1 \mathrm{~cm}$ and weight by electronic scale to the nearest $0.1 \mathrm{~kg}$, and laboratory testing, including free thyroxine (free T4) by competitive immunoassay (CV 5.8-7.3\%), thyroid stimulating hormone (TSH) (CV 4.9\%), follicle stimulating hormone (FSH) (CV 5.8-6.1\%), and insulinlike growth factor-1 (IGF-1) (CV 5.2-6.4\%) by chemiluminescent immunoassay (Siemens Healthcare Diagnostics, Tarrytown, NY); and interleukin-6 (IL-6) (CV 14.5\%) by ELISA (R\&D Systems, Minneapolis, MN), adiponectin (CV 17.1\%) and leptin (CV 13.7\%) by 2-plex competitive immunoassay on the Luminex platform (Austin, TX) using bead sets from R\&D Systems (Minneapolis, MN). GH stimulation test using clonidine and arginine was performed. GH deficiency was defined as a stimulated peak GH level less than $7 \mathrm{mcg} / \mathrm{L}$, which is a more conservative cutoff than $10 \mathrm{mcg} / \mathrm{L}$, which is frequently used in clinical practice to diagnose GH deficiency [25]. Total body (not excluding head) BMD, posterior anterior lumbar spine (L2-L4), and body composition (percent body fat and lean body mass) were assessed by dual-energy $x$-ray absorptiometry (DXA) (G.E. Lunar Prodigy scanner; pediatric software version 9.3; Madison, WI, USA), and bone age by the Greulich and Pyle method [26]. Dietary intake was evaluated using the Youth/Adolescent Questionnaire (YAQ) $[27,28]$. Physical activity, including television/computer screen time, was assessed by the Modifiable Activity Questionnaire for Adolescents [29]. The diagnoses of hypogonadism was made by either participant report of a history of diagnosed hypogonadism or for males an LH > $10 \mathrm{IU} / \mathrm{L}$ and testosterone below the lower end of reference range for pubertal stage and for females an FSH $>40 \mathrm{IU} / \mathrm{L}$. The diagnosis of hypothyroidism was made by participant report, high TSH $(>5.0 \mathrm{uU} /$ $\mathrm{mL})$ and normal free $\mathrm{T} 4$, or low free $\mathrm{T} 4(<0.8 \mathrm{ng} / \mathrm{dL})$. Height and weight Z-scores were calculated based on 2000 Centers for Disease Control growth charts.

According to current International Society for Clinical Densitometry (ISCD) recommendation the terms osteoporosis should be limited to children with low BMD (Zscore $\leq-2)$ accompanied by fractures [30]. Since very few patients met the definition of osteoporosis or low BMD in our study, yet a substantial proportion of patients had BMD below average, we defined a mild BMD deficit as a $\mathrm{Z}$-score $\leq-1$. This cutoff has been used in other studies describing bone deficits in CCS [22,31]. The rationale for using this cutoff is that those with lower BMD Z-scores are likely to remain in the low end of the normal range [32] and reach a lower peak BMD [11] thus increasing their lifetime risk of osteoporosis and fracture. In addition, any decrease in BMD Z- score predisposed children to an increased risk of fracture [33,34].

\section{Statistical analysis}

Descriptive statistics are expressed as frequencies and percents or mean \pm standard error (SE), as appropriate. Regression models based on generalized estimating equations (GEE) with robust variance estimates were used to compare measures between CCS and the sibling control group with adjustments as noted in tables, to appropriately account for intra-family correlation. Among CCS, multivariable logistic regression was used to evaluate odds ratios (OR) for the associations between Z-score $\leq$ -1 of the whole body BMD and lumbar spine BMD with the following predictors: age at diagnosis, time since diagnosis, GH Status (GH deficient, not GH deficient), 
IGF-1 SDS $(\leq-2,>-2)$, percent body fat, lean body mass, body mass index (BMI), IL-6, adiponectin, leptin, calcium intake, vitamin D intake, zinc intake, omega-3 intake, protein intake, milk intake, fruit and vegetable intake, physical activity score, television/computer screen time, time elapsed since diagnosis, radiation and steroid exposure. All models were adjusted for sex, age-at-study, ethnicity (white-not-Hispanic, others), and pubertal Tanner stage.

The assumption of linearity for continuously valued factors was evaluated using Generalized Additive Models (GAM) [35], and relevant categorical variables were created for those that were significantly non-linear at the alpha $=0.05$ level, and, for adiponectin, leptin and IGF-1 to minimize undue influence by extremely large values [35]. Age at study (whole body analysis only), IL-6, time elapsed since diagnosis (lumbar spine analysis only), and calcium were categorized per non-linear relationship with the outcomes. Category cut points were selected based on visual inspection of predicted curves from GAM models, and practical considerations regarding numbers of events per category. Because of correlation between percent body fat and leptin in both the whole body and lumbar spine models, separate multivariable models were developed including either leptin or percent body fat. Because of correlation between hypogonadism and hypothyroidism in the lumbar spine model, separate multivariable models were developed including either hypothyroidism or hypogonadism. Five models were evaluated: model 1: IGF-1 SDS, hypothyroidism and/or hypogonadism; model 2: lean body mass, percent fat mass (or leptin), television/computer screen time, physical activity score, years since diagnosis and IL-6; model 3: milk, protein, fruits/vegetable and daily total caloric intakes; model 4: protein, vitamin D, zinc, calcium, omega-3 and daily total caloric intakes; model 5: radiation and steroid exposure. All models were adjusted for age at study, sex, pubertal Tanner stage, and ethnicity. All p-values are two-sided and those $<0.05$ were considered statistically significant, and those between 0.05 and 0.10 suggestive of association.

\section{Results}

\section{Participant characteristics}

We evaluated 527 participants, 319 childhood cancer survivors (148 females) aged 9-18 years and 208 controls (97 females) aged 9-18 years (Table 1). CCS were slightly older than controls, however pubertal Tanner stage was similar between groups. CCS were generally of normal stature, but were shorter than controls. Percent body fat was higher and lean body mass lower in CCS, and there were significantly more CCS with obesity $(B M I \geq 95 \%)$ than controls.

By history or laboratory assessment on day of study, 2 CCS had type 1 diabetes mellitus, 2 had type 2 diabetes mellitus, 31 had hypothyroidism (all on treatment with normal free T4 levels on day of study), 22 had hypogonadism, 4 had precocious puberty and 16 (5\%) had short stature (height less than $3^{\text {rd }}$ percentile for age and gender). Thirty-six (13\%) CCS were diagnosed with GH deficiency by stimulation testing at the time of the study and $34(11 \%)$ were diagnosed prior to study entry. For CCS, the average age at cancer diagnosis was $4.5 \pm 0.2$ years (range $0-12.5$ years), and the average time since treatment was $10.1 \pm 0.2$ years (range $4.3-17.8$ years). The median radiation dose in 31 CCS participants treated with CNS radiation was 2370 cGY (range 1800-5580 cGY). The median number of days of steroid treatment in 133 CCS treated with steroids was 162 days (range 4302 days) and the median dose $7,520 \mathrm{mg} / \mathrm{kg} /$ day prednisone equivalents (range $200-15,250 \mathrm{mg} / \mathrm{kg} /$ day prednisone equivalents).

\section{Bone mineral density}

CCS were significantly more likely to have both whole body and lumbar spine BMD Z-score $\leq 1$ (Figure 1) as compared to controls. The mean whole body BMD Zscore and lumbar spine BMD Z-score were lower in CCS vs. controls (unadjusted mean \pm SEM: $0.3 \pm 0.07$ CCS vs. $0.6 \pm 0.07$ controls; $p=0.002$, and $-0.2 \pm 0.06$ CCS vs. 0.1 \pm 0.07 controls; $\mathrm{p}=0.02$ respectively); however, after adjusting for height SDS there was no difference in whole body or lumbar spine BMD Z-scores. There were very few CCS (whole body $\mathrm{N}=7$ (2.3\%), lumbar $\mathrm{N}=11$ $(3.5 \%)$ ) or controls (whole body $=0$, lumbar $=0$ ) with BMD Z-scores $\leq-2$. There was no evidence of differential time-since diagnosis effects between subjects who were < 10 years compared to those $\geq 10$ years at diagnosis.

\section{Factors associated with reduced BMD in childhood cancer survivors}

In multivariable analysis, testing age, gender, ethnicity, pubertal Tanner stage, IGF-1 SDS and hypothyroidism and/or hypogonadism (model 1), CCS with hypogonadism were 9.1 times more likely to have whole body BMD Z-score $\leq-1$ (95\% CI: 3.3-25.3; p < 0.001) and 4.4 times more likely to have lumbar spine BMD Z-score $\leq-1(95 \%$ CI: $1.7-11.4 ; \mathrm{p}=0.002)$. CCS with hypothyroidism were 2.9 times more likely to have lumbar spine BMD Z-score $\leq-1$ (95\% CI: 1.3-6.6; $\mathrm{p}=0.012$ ). Both hypogonadism and hypothyroidism can cause short stature. Therefore, we added height SDS to the modeling and found similar results. CCS with hypogonadism were 11.2 times more likely to have whole body BMD Z-score $\leq-1$ (95\% CI: 3.7-35.8; $<<0.001$ ) and 4.3 times more likely to have lumbar spine BMD Z-score $\leq-1$ (95\% CI: 1.6-11.8; $\mathrm{p}=$ $0.003)$. CCS with hypothyroidism were 2.8 times more likely to have lumbar spine BMD Z-score $\leq-1$ (95\% CI: 1.2-6.7; $p=0.017)$. Neither GHD nor low IGF-1 SDS 


\begin{tabular}{|c|c|c|c|c|}
\hline & & $\operatorname{CCS}(n=319)$ & Controls $(\mathrm{n}=$ & \\
\hline & & Mean $\pm \mathrm{SE}$ & Mean $\pm \mathrm{SE}$ & $P$ \\
\hline Age at Study & & $14.5 \pm 0.1$ & $13.7 \pm 0.2$ & $<0.001$ \\
\hline Height, Z-sco & & $0.1 \pm 0.1$ & $0.4 \pm 0.1$ & $<0.001$ \\
\hline Weight, Z-scc & & $0.5 \pm 0.1$ & $0.6 \pm 0.1$ & 0.363 \\
\hline$\%$ Body Fat ${ }^{\dagger}$ & & $28.1 \pm 0.8$ & $25.9 \pm 0.9$ & 0.007 \\
\hline Fat Mass, $\mathrm{kg}^{\dagger}$ & & $16.5 \pm 0.7$ & $14.8 \pm 0.8$ & 0.024 \\
\hline Lean Body M & & $38.5 \pm 0.5$ & $39.8 \pm 0.6$ & 0.015 \\
\hline IGF-1 SDS & & $-1.24 \pm 0.05$ & $-1.04 \pm 0.06$ & 0.004 \\
\hline$|\mathrm{L}-6, \mathrm{pg} / \mathrm{m}|^{\dagger}$ & & $1.4 \pm 0.1$ & $1.6 \pm 0.3$ & 0.505 \\
\hline Bone Age, ye & & $14.5 \pm 0.1$ & $13.8 \pm 0.2$ & $<0.001$ \\
\hline Relative Bone & & $1.01 \pm 0.01$ & $1.01 \pm 0.01$ & 0.425 \\
\hline Tanner Score & & $3.6 \pm 0.1$ & $3.3 \pm 0.1$ & 0.068 \\
\hline Calcium Intak & & $1280 \pm 30$ & $1257 \pm 38$ & 0.575 \\
\hline Vitamin D Int & & $331 \pm 10$ & $330 \pm 12$ & 0.968 \\
\hline Physical Activ & inutes per week & $58.6 \pm 3.8$ & $65.9 \pm 4.9$ & 0.191 \\
\hline & & $\mathrm{N}$ (Percent) & $\mathrm{N}$ (Percent) & \\
\hline Screen time & $>1 \mathrm{hr} /$ day & $225(75.5)$ & $147(73.9)$ & 0.680 \\
\hline & 0-1 hr/day & $73(24.5)$ & $52(26.1)$ & \\
\hline Ethnicity & White/not Hispanic & $274(85.9)$ & 194 (93.3) & $<0.001$ \\
\hline & Others & $45(14.1)$ & $14(6.7)$ & \\
\hline Sex & Males & $171(53.6)$ & $111(53.4)$ & 0.956 \\
\hline & Females & $148(46.4)$ & $97(46.6)$ & \\
\hline $\mathrm{BMI}$ & $<5 \%$ & $9(2.8)$ & $4(1.9)$ & 0.495 \\
\hline & $\geq 5 \%$ to $<85 \%$ & $210(65.8)$ & $137(65.9)$ & 0.995 \\
\hline & $\geq 85 \%$ to $<95 \%$ & $42(13.2)$ & $43(20.7)$ & 0.031 \\
\hline & $\geq 95 \%$ & $58(18.2)$ & $24(11.5)$ & 0.028 \\
\hline
\end{tabular}

${ }^{\dagger}$ Adjusted for age, sex, ethnicity, and pubertal Tanner stage

Relative Bone age $=$ Bone age/actual age; $\mathrm{MET}=$ metabolic equivalent

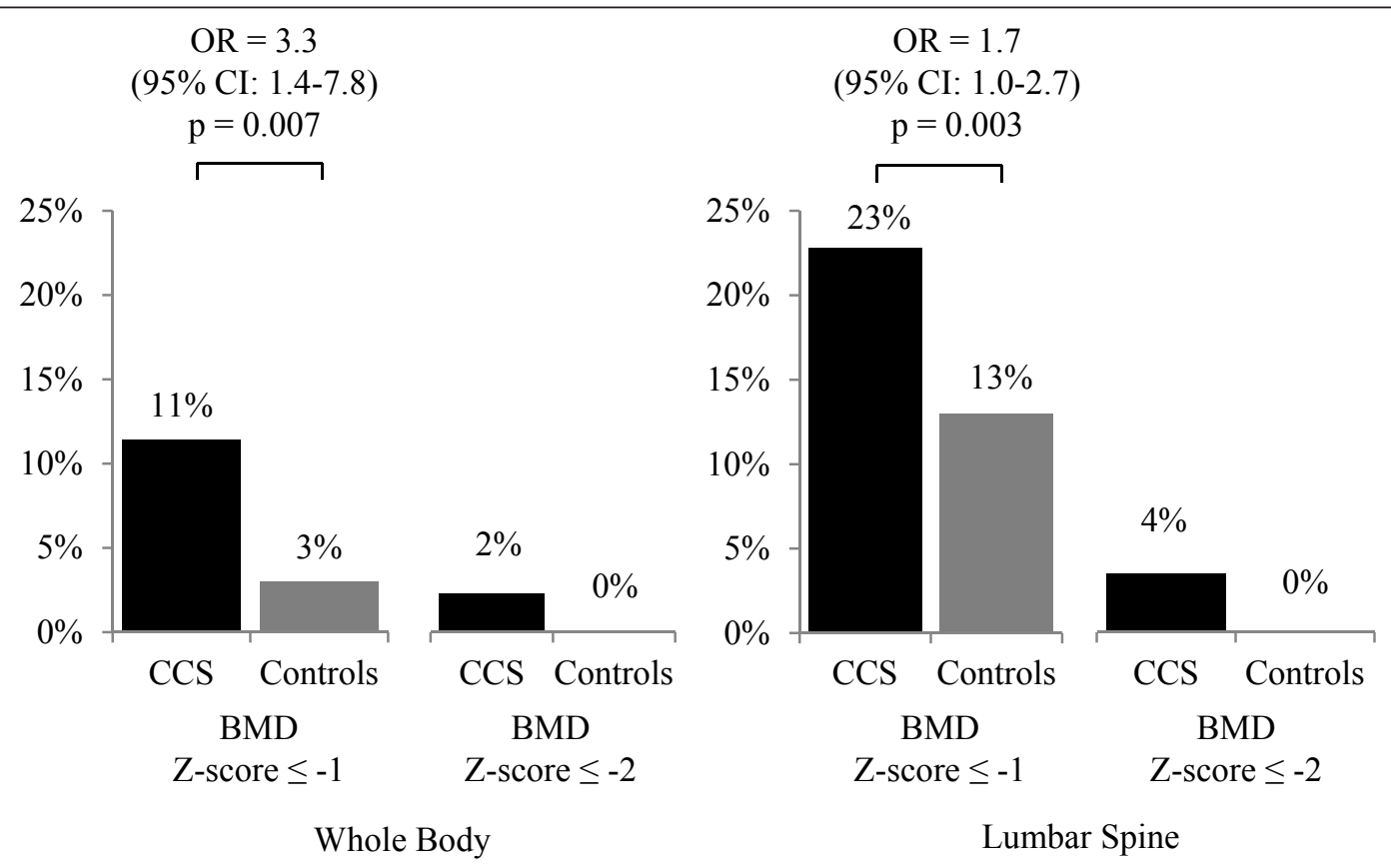

Figure 1 Whole body and lumbar spine bone deficits in childhood cancer survivors (CCS) compared to controls. Odds ratio (OR) adjusted for sex, age-at-study, ethnicity (white-not-Hispanic, others), and pubertal Tanner stage are presented for BMD Z-score $\leq-1 ;$ OR for BMD Z-score $\leq-2$ unable to be calculated due to $0 \%$ prevalence in controls. 
increased the odds of whole body or lumbar spine BMD $Z$-score $\leq-1$. We were next interested in potential effects of a sedentary lifestyle (obesity and low lean body mass) and hormones influenced by adiposity (IL-6, adiponectin, leptin) on bone density. Given the influence of GH deficiency on lean body mass we evaluated the association between lean body mass and GH deficiency; as there was no significant association $(\mathrm{p}=0.12)$ we did not include $\mathrm{GH}$ deficiency in these models. In whole body multivariate modeling of lean body mass, percent fat mass (or leptin), television/computer screen time, physical activity score, years since diagnosis and IL-6 (model 2), CCS with higher IL-6 (> $2.5 \mathrm{pg} / \mathrm{ml})$, two or more hours of television/ computer screen time per day, and lower lean body mass, were more likely to have whole body BMD Z-score $\leq-1$. Percent body fat, adiponectin, years since diagnosis, and physical activity score were not significantly associated with whole body BMD Z-score $\leq-1$ (Tables 2 and 3). The addition of height SDS to this model did not change theses associations and did not independently influence the odds of BMD Z-score $\leq-1$. In contrast to the results for whole body BMD, in lumbar spine multivariate modeling, IL-6 and screen time were not associated with BMD. However, even after adjusting for age, sex, and pubertal stage, both

\begin{tabular}{|c|c|c|c|c|}
\hline \multicolumn{5}{|c|}{ Outcome: Whole Body BMD Z-score $\leq-1$} \\
\hline & Categories & OddsRatio & $95 \% \mathrm{Cl}$ & $P$ \\
\hline \multirow[t]{2}{*}{ Age at study } & $\leq 16$ years & 1.0 & - & - \\
\hline & $>16$ years & 2.5 & $0.8-8.1$ & 0.125 \\
\hline \multirow[t]{2}{*}{ Ethnicity } & Other & 1.0 & - & - \\
\hline & $\begin{array}{l}\text { White non- } \\
\text { Hispanic }\end{array}$ & 1.7 & $0.5-6.9$ & 0.420 \\
\hline Tanner stage, 1-5 & $\begin{array}{l}\text { One stage } \\
\text { increase }\end{array}$ & 2.2 & $1.3-3.8$ & 0.006 \\
\hline \multirow[t]{2}{*}{ Sex } & Female & 1.0 & - & - \\
\hline & Male & 2.6 & $\begin{array}{l}0.8- \\
10.0\end{array}$ & 0.137 \\
\hline Percent Body Fat & $1 \%$ increase & 0.95 & $0.9-1.0$ & 0.070 \\
\hline Lean Body Mass & $1 \mathrm{~kg}$ increase & 0.85 & $0.8-0.9$ & $\begin{array}{l}< \\
0.001\end{array}$ \\
\hline \multirow[t]{2}{*}{ Years Since Diagnosis } & $5-9$ years & 1.0 & - & - \\
\hline & $>9.0$ years & 2.3 & $0.9-6.3$ & 0.080 \\
\hline \multirow[t]{2}{*}{ IL-6 } & $\leq 2.5 \mathrm{ng} / \mathrm{dl}$ & 1.0 & - & - \\
\hline & $>2.5 \mathrm{ng} / \mathrm{dl}$ & 4.4 & $\begin{array}{l}1.5- \\
12.9\end{array}$ & 0.007 \\
\hline \multirow{2}{*}{$\begin{array}{l}\text { Screen time*, per } \\
\text { day }\end{array}$} & $0-1$ hours & 1.0 & - & - \\
\hline & $\geq 2$ hours & 4.1 & $\begin{array}{l}1.3- \\
18.6\end{array}$ & 0.033 \\
\hline
\end{tabular}

Physical activity score and adiponectin were not significant factor $\mathrm{s}$ ( $\mathrm{p}$-value $>$ 0.1 ) and were therefore removed from the model

*Screen time $=$ television and computer screen time decreases in physical activity score and lower lean body mass $(\leq 35 \mathrm{~kg})$ were significantly associated with the odds of lumbar spine BMD Z-score $\leq-1$; after the addition of height SDS to this model, the odds ratio for lean body mass was attenuated (OR 2.9, 95\%CI: 1.2-7.4; $\mathrm{p}=0.02$ ) although height SDS did not independently influence the odds of lumbar spine BMD Z-score $\leq-1$.

Percent body fat and years since diagnosis were not associated with lumbar spine BMD Z-score $\leq-1$ (Tables 2 and 3). Leptin and percent body fat were strongly correlated; therefore, two models were built, one that excluded leptin, and one that excluded percent body fat. Similarly, when leptin was substituted for percent body fat, it was not significantly associated with whole body or lumbar spine BMD.

Of all the dietary and nutrient factors (model 3: milk, protein, fruits/vegetable and daily total caloric intake and model 4: protein, vitamin $\mathrm{D}$, zinc, calcium, omega-3 and daily total caloric intake), only total protein was a marginally significant predictor of whole body BMD Zscore $\leq-1(p=0.055)$ : the odds of whole body BMD Zscore $\leq-1$ were $3 \%$ lower for each additional 1 gram of total protein intake. There were no significant associations in model 4.

Finally, the odds of whole body or lumbar spine BMD Z-score $\leq-1$ were significantly higher for both those with CNS radiation and with other radiation, as compared to those with no radiation (Tables 4 and 5); however when height SDS was added to the model the odds of lumbar spine BMD Z-score $\leq-1$ (but not for whole body) were significantly attenuated for those who received CNS or other radiation. The odds of lumbar BMD Z-score $\leq-1$ for those exposed to steroids were almost twice that for those who did not receive steroids (Tables 4 and 5); when height SDS was added to the model the odds were significantly attenuated. The association between whole body BMD Z-score $\leq-1$ and steroids was not significant with or without height SDS in the model. Subjects with a higher steroid exposure, a more recent history of steroid exposure or a longer duration of steroid exposure did not show larger BMD deficits.

\section{Discussion}

In this study of childhood cancer survivors (CCS) $<18$ years of age whole body and lumbar spine BMD deficiencies (BMD Z-scores $\leq-1$ ) were significantly more common than in a healthy sibling control group. This is important for lifetime bone health, because children with BMD Z-scores $\leq-1$ are likely to have a lower peak bone density that sets them up for early osteoporosis and increased risk for fracture later in life. In addition, even during childhood, lower BMD Z-scores are associated with increased risk of fracture $[33,34,36]$. 
Table 3 Multivariable analysis in CCS of sedentary lifestyle (obesity and low lean body mass) and hormones influenced by adiposity (IL-6 and adiponectin) associated with BMD Z-score $\leq-1$

\begin{tabular}{|c|c|c|c|c|}
\hline \multicolumn{5}{|c|}{ Outcome: Lumbar spine BMD Z-score $\leq-1$} \\
\hline & Categories & OddsRatio & $95 \% \mathrm{Cl}$ & $P$ \\
\hline Age at Study & 1 year increase & 2.2 & $1.7-3.0$ & $<0.001$ \\
\hline \multirow[t]{2}{*}{ Ethnicity } & Other & 1.0 & - & - \\
\hline & White non-Hispanic & 2.6 & $0.9-9.1$ & 0.104 \\
\hline Tanner, 1-5 & One stage increase & 0.4 & $0.2-0.7$ & $<0.001$ \\
\hline \multirow[t]{2}{*}{ Sex } & Female & 1.0 & - & - \\
\hline & Male & 1.6 & $0.7-3.4$ & 0.270 \\
\hline \multirow[t]{2}{*}{ Lean Body Mass } & $>35 \mathrm{~kg}$ & 1.0 & - & - \\
\hline & $\leq 35 \mathrm{~kg}$ & 4.1 & $1.8-9.6$ & $<0.001$ \\
\hline Percent Body Fat & $1 \%$ increase & 0.97 & $0.94-1.0$ & 0.088 \\
\hline Physical Activity Score & One unit increase & 0.99 & $0.99-1.0$ & 0.042 \\
\hline
\end{tabular}

Years since diagnosis, IL-6, adiponectin, and screen time were not significant factors ( $p$-value $>0.1$ ) and were therefore removed from the model

Although we have no longitudinal data, we found no cross-sectional evidence to suggest "catch-up" in BMD for participants treated at a younger, pre-pubertal, age ( $<10$ years) and confirmed that hypogonadism is associated with bone deficits in CCS. Finally, we identified modifiable factors associated with lower BMD in CCS: lower lean body mass (independent of GH deficiency status), higher daily television/computer screen, lower physical activity score, and higher IL-6. These risk factors may be targets for medical and lifestyle interventions to increase bone density and decrease the risk of early osteoporosis and fracture in children with CCS.

We found that lower lean body mass increased the likelihood of having a BMD Z-score $\leq-1$ independent of the influence of GH deficiency which was not associated with lean body mass. CCS had significantly lower lean body

Table 4 Multivariable analysis of cancer treatment factors associated with BMD Z-score $\leq-1$

\begin{tabular}{|c|c|c|c|c|}
\hline \multicolumn{5}{|c|}{ Outcome: Whole body BMD Z-score $\leq-1$. } \\
\hline & Category & OddsRatio & $95 \% \mathrm{Cl}$ & $P$ \\
\hline \multirow[t]{2}{*}{ Age at Study } & $\leq 16$ years & 1.0 & - & - \\
\hline & $>16$ years & 2.0 & $0.8-5.3$ & 0.177 \\
\hline \multirow[t]{2}{*}{ Ethnicity } & Other & 1.0 & - & - \\
\hline & $\begin{array}{l}\text { White non- } \\
\text { Hispanic }\end{array}$ & 0.9 & $0.3-2.9$ & 0.800 \\
\hline Tanner stage, 1-5 & $\begin{array}{l}\text { One stage } \\
\text { increase }\end{array}$ & 0.9 & $0.6-1.4$ & 0.666 \\
\hline \multirow[t]{2}{*}{ Sex } & Females & 1.0 & - & - \\
\hline & Males & 1.2 & $0.5-2.5$ & 0.704 \\
\hline \multirow{3}{*}{$\begin{array}{l}\text { Radiation } \\
\text { Exposure }\end{array}$} & None & 1.0 & - & - \\
\hline & CNS Radiation & 7.9 & $\begin{array}{l}3.0- \\
20.8\end{array}$ & $\begin{array}{l}< \\
0.001\end{array}$ \\
\hline & Other Radiation & 5.7 & $\begin{array}{l}2.3- \\
13.9\end{array}$ & $\begin{array}{l}< \\
0.001\end{array}$ \\
\hline
\end{tabular}

Steroid exposure was not a significant factor $(p$-value $>0.1)$ and was therefore removed from the model mass than controls; clinically we suspected this was at least in part due to decreased physical activity in CCS; however we did not find a difference in physical activity score between CCS and controls. This may be due to the limitations of quantifying physical activity by questionnaire. Other studies in healthy pediatric populations have shown that increased muscle mass is associated with increased bone mineral content, density, and estimated bone strength [37-40] and that lean body mass, along with male gender and physical activity, can explain up to $37 \%$ of total variance in BMD in healthy, prepubertal children [41]. Therefore, these reports suggest that interventions aimed at increasing lean body mass may improve bone density and strength in CCS.

Although physical activity was no different between CCS and controls, lower physical activity in CCS increased the likelihood of having a BMD Z-score $\leq-1$. The long-term beneficial impact of increased physical activity on bone was demonstrated in a twin study showing that twins with higher levels of leisure time physical

Table 5 Multivariable analysis of cancer treatment factors associated with BMD Z-score $\leq \mathbf{- 1}$

\begin{tabular}{lllll}
\hline Outcome: Lumbar & spine BMD Z-score $\leq \mathbf{- 1 .}$ & & \\
& Category & OddsRatio & $\mathbf{9 5 \% C l}$ & $\boldsymbol{P}$ \\
\hline Age at Study & $\leq 16$ years & 1.0 & - & - \\
& $>16$ years & 3.1 & $1.4-7.1$ & $\mathbf{0 . 0 0 6}$ \\
Ethnicity & Other & 1.0 & - & - \\
& White non-Hispanic & 2.2 & $0.9-6.7$ & 0.135 \\
Tanner stage, 1-5 & One stage increase & 0.7 & $0.5-0.9$ & $\mathbf{0 . 0 1 5}$ \\
Sex & Female & 1.0 & - & - \\
\multirow{4}{*}{ Radiation Exposure } & Male & 1.1 & $0.6-1.9$ & 0.732 \\
& None & 1.0 & - & - \\
& Cranial Radiation & 2.5 & $1.0-5.7$ & $\mathbf{0 . 0 4 0}$ \\
Steroid Exposure & Other Radiation & 2.4 & $1.0-5.5$ & $\mathbf{0 . 0 4 1}$ \\
& No & 1.0 & - & - \\
& Yes & 1.9 & $1.0-3.5$ & $\mathbf{0 . 0 4 2}$
\end{tabular}


activity for at least 30 years had higher estimated bending and compression strength of bone [42]. Increased physical activity has also been shown to improve bone health in healthy children [43]. Studies on the relationship between physical activity and measures of bone health in CCS have reported either positive associations, similar to our data $[2,6,15,32]$, or no associations $[4,7,21,44]$. Some of the variability in results is likely related to limitations of activity questionnaires to accurately measure activity level and/or intensity. Adding accelerometers to questionnaires to measure physical activity in CCS uncovered a positive correlation between activity levels and both whole body BMD and estimated volumetric lumbar spine BMD [2] and may provide a more accurate assessment of daily activity level.

Television/computer screen time is used as a surrogate measure of physical activity [45]. The present cohort was divided between CCS who watched television/computer screen for $\geq 2$ hours per day versus $<2$ hours per day; the CCS with the higher television/computer screen were more likely to have whole body BMD Z-scores $\leq-1$. This is similar to a prior report that time spent on television and computers negatively correlated with BMD Z-scores in CCS [5]. In contrast, no association between viewing time and bone measures were found in another study of CCS [3]. The equivocal findings again may be due to limitations in using television viewing time as a surrogate measure for activity. In addition, intensity of exercise is not accounted for when simply quantifying television/ computer screen time.

Higher levels of the inflammatory cytokine IL- 6 were associated with a BMD Z-score $\leq-1$ in this cohort of CCS. Although we did not measure markers of bone turnover, other studies have shown that IL-6 can induce osteoclastogenesis [46], increase bone resorption [47], and inhibit bone formation by osteoblasts [48]. Studies in adult men and women, before and after menopause, have shown associations between higher levels of IL- 6 and osteoporosis [49-51], and baseline IL-6 levels have predicted bone loss over a 3 year period in older adults [52]. Higher levels of IL- 6 have also been shown to correlate with osteoporosis and other bone deficits in patients with chronic inflammatory diseases such as rheumatoid arthritis [53] and inflammatory bowel disease [54], as well as patients who underwent HCT [55-59]. The current study is the first to report such an association in CCS who have not received HCT.

A limitation of this study is that the bone density data were collected by DXA. DXA provides a 2-dimensional image that can result in a falsely decreased BMD in children who are small for their age simply due to small bone size [60-63]. A potential example of this in our study was the finding that mean BMD Z-scores were significantly different between CCS and healthy siblings before adjustment for height SDS, but not significantly different after adjusting for height SDS. However, CCS were on average shorter than the healthy siblings and so it is impossible to distinguish by DXA measurements whether the influence of height SDS is due to DXA underestimating BMD in shorter individuals or simply that height SDS is acting as an indicator of being in the CCS group. The mean height in our CCS cohort was normal $(0.1 \pm 01$ SDS $)$ therefore we would not expect a significant underestimation of BMD by DXA. DXA is also limited in that it cannot distinguish between cortical and trabecular bone or estimate bone strength. Future studies of bone health in CCS should consider performing peripheral quantitative computer tomography (pQCT) scans to limit the impact of short stature on BMD and evaluate potential variation in impact on cortical versus trabecular bone. DXA is clinically useful because of low radiation exposure, short time required for scanning, and ample amount of scientific literature in pediatric populations. Importantly, studies have shown that not only low BMD Z-score, but any decrease in BMD Z-score predisposes children to an increased risk of fractures [33,34]. An additional limitation is that markers of bone turnover and vitamin D levels were not measured; vitamin D intake was used as a surrogate marker for $25-\mathrm{OH}$ vitamin D level. Finally, in this cross-sectional study it is not possible to make any inference on causality. Despite these limitations, the study documents the presence of mild bone deficits in childhood cancer survivors (even before they reach adulthood) and identifies potentially modifiable factors associated with bone deficits.

\section{Conclusions}

In conclusion, this is the first study comparing bone health measures between CCS and a sibling control group during childhood. We found that CCS had lower lumbar spine and total body BMD than the controls, and that although reported activity levels were no different between groups, CCS had lower lean body mass than the controls. Within the CCS group, the results show that lower lean body mass, lower levels of physical activity, higher daily television viewing time, higher IL-6 levels, hypogonadism and exposure to radiation or steroids increased the likelihood of having a BMD Z-score $\leq-1$. In addition, contrary to what we expected, treatment before puberty and length of time since treatment did not influence risk of having bone deficits. A BMD Zscore $\leq-1$ is expected to increase both the current and lifetime risk of fracture. Although we have not shown causality between any of these measures and bone health, prospective data in other populations support the bone health benefits of increasing lean body mass through activity and resistance exercises. Finally, our finding of the association of IL-6 with measures of bone health 
identifies a novel potential treatment target to prevent osteoporosis in CCS and requires prospective studies to determine what if any impact modification of this inflammatory variable will have on bone health in CCS.

\section{Acknowledgements}

The project described was supported by RO1CA113930-01A1 from the National Cancer Institute, M01-RR00400 from the National Center for Research Resources, and the Children's Cancer Research Fund (JS).

\section{Author details}

'Department of Pediatrics, University of Minnesota, Minneapolis, MN, USA. ${ }^{2}$ Department of Pediatrics, University of California San Diego and Rady Children's Hospital, San Diego, CA, USA. ${ }^{3}$ Clinical Research Division, Fred Hutchinson Cancer Research Center, Seattle, WA, USA. ${ }^{4}$ School of Public Health, University of Minnesota, Minneapolis, MN, USA. ${ }^{5}$ Children's Hospitals \& Clinics of Minnesota, Minneapolis, MN, USA. 'School of Kinesiology, University of Minnesota, Minneapolis, MN, USA. ${ }^{7}$ Pediatric Endocrinology, University of Minnesota, East Building Room MB671 2450 Riverside Ave., Minneapolis, MN 55454, USA.

\section{Authors' contributions}

LEP and AP conceived of the study, participated in its design and interpretation of data, and helped to draft the manuscript. WL and PG performed the statistical analysis. ACD, ARS, WL, PG, LMS, JLP, DRD, KSB and JS participated in analysis and interpretation of data and revising the manuscript critically for important intellectual content. All authors read and approved the final manuscript.

\section{Competing interests}

The authors declare that they have no competing interests.

Received: 26 September 2011 Accepted: 28 March 2012 Published: 28 March 2012

\section{References}

1. Consensus development conference: diagnosis, prophylaxis, and treatment of osteoporosis. Am J Med 1993, 94(6):646-650.

2. Tillmann V, Darlington AS, Eiser C, Bishop NJ, Davies HA: Male sex and low physical activity are associated with reduced spine bone mineral density in survivors of childhood acute lymphoblastic leukemia. J Bone Miner Res 2002, 17(6):1073-1080.

3. Kelly KM, Thornton JC, Hughes D, Osunkwo I, Weiner M, Wang J, Horlick M: Total body bone measurements: a cross-sectional study in children with acute lymphoblastic leukemia during and following completion of therapy. Pediatr Blood Cancer 2009, 52(1):33-38.

4. Kadan-Lottick N, Marshall JA, Baron AE, Krebs NF, Hambidge KM, Albano E: Normal bone mineral density after treatment for childhood acute lymphoblastic leukemia diagnosed between 1991 and 1998. J Pediatr 2001, 138(6):898-904.

5. Gunes AM, Can E, Saglam H, Ilcol YO, Baytan B: Assessment of bone mineral density and risk factors in children completing treatment for acute lymphoblastic leukemia. J Pediatr Hematol Oncol 2010, 32(3): e102-e107.

6. Chaiban J, Muwakkit S, Arabi A, Jomaa L, Daouk LO, El-Rassi R, Abboud M, El-Hajj Fuleihan G: Modeling pathways for low bone mass in children with malignancies. J Clin Densitom 2009, 12(4):441-449.

7. Barr RD, Simpson T, Webber CE, Gill GJ, Hay J, Eves M, Whitton AC: Osteopenia in children surviving brain tumours. Eur J Cancer 1998, 34(6):873-877.

8. Athanassiadou F, Tragiannidis A, Rousso I, Katsos G, Sidi V, Papageorgiou T, Papastergiou C, Tsituridis I, Koliouskas D: Bone mineral density in survivors of childhood acute lymphoblastic leukemia. Turk J Pediatr 2006, 48(2):101-104.

9. Ross PD: Osteoporosis. Frequency, consequences, and risk factors. Arch Intern Med 1996, 156(13):1399-1411.

10. Bliuc D, Nguyen ND, Milch VE, Nguyen TV, Eisman JA, Center JR: Mortality risk associated with low-trauma osteoporotic fracture and subsequent fracture in men and women. JAMA 2009, 301(5):513-521.
11. Baxter-Jones AD, Faulkner RA, Forwood MR, Mirwald RL, Bailey DA: Bone mineral accrual from 8 to 30 years of age: An estimation of peak bone mass. J Bone Miner Res 2011, 26(8):1729-1739.

12. Ross PD, Davis JW, Epstein RS, Wasnich RD: Pre-existing fractures and bone mass predict vertebral fracture incidence in women. Ann Intern Med 1991, 114(11):919-923.

13. Strauss AJ, Su JT, Dalton VM, Gelber RD, Sallan SE, Silverman LB: Bony morbidity in children treated for acute lymphoblastic leukemia. J Clin Oncol 2001, 19(12):3066-3072.

14. Mandel K, Atkinson S, Barr RD, Pencharz P: Skeletal morbidity in childhood acute lymphoblastic leukemia. J Clin Oncol 2004, 22(7):1215-1221.

15. Jarfelt $M$, Fors $H$, Lannering $B$, Bjarnason R: Bone mineral density and bone turnover in young adult survivors of childhood acute lymphoblastic leukaemia. Eur J Endocrinol 2006, 154(2):303-309.

16. Henderson RC, Madsen CD, Davis C, Gold SH: Bone density in survivors of childhood malignancies. J Pediatr Hematol Oncol 1996, 18(4):367-371.

17. Vassilopoulou-Sellin R, Brosnan P, Delpassand A, Zietz H, Klein MJ, Jaffe N: Osteopenia in young adult survivors of childhood cancer. Med Pediatr Oncol 1999, 32(4):272-278.

18. Nysom K, Holm K, Michaelsen KF, Hertz H, Muller J, Molgaard C: Bone mass after treatment of malignant lymphoma in childhood. Med Pediatr Oncol 2001, 37(6):518-524.

19. Nysom K, Holm K, Michaelsen KF, Hertz H, Muller J, Molgaard C: Bone mass after treatment for acute lymphoblastic leukemia in childhood. J Clin Oncol 1998, 16(12):3752-3760.

20. Kaste SC, Jones-Wallace D, Rose SR, Boyett JM, Lustig RH, Rivera GK, Pui CH, Hudson MM: Bone mineral decrements in survivors of childhood acute lymphoblastic leukemia: frequency of occurrence and risk factors for their development. Leukemia 2001, 15(5):728-734

21. Arikoski P, Komulainen J, Voutilainen R, Riikonen P, Parviainen M, Tapanainen P, Knip M, Kroger H: Reduced bone mineral density in longterm survivors of childhood acute lymphoblastic leukemia. J Pediatr Hematol Oncol 1998, 20(3):234-240.

22. Thomas IH, Donohue JE, Ness KK, Dengel DR, Baker KS, Gurney JG: Bone mineral density in young adult survivors of acute lymphoblastic leukemia. Cancer 2008, 113(11):3248-3256.

23. Aisenberg J, Hsieh K, Kalaitzoglou G, Whittam E, Heller G, Schneider R, Sklar C: Bone mineral density in young adult survivors of childhood cancer. J Pediatr Hematol Oncol 1998, 20(3):241-245.

24. Tanner JM: Assessment of skeletal maturity and prediction of adult height (TW2 method) London; New York: Academic Press; 1975.

25. Consensus guidelines for the diagnosis and treatment of growth hormone (GH) deficiency in childhood and adolescence: summary statement of the GH Research Society. GH Research Society. I Clin Endocrinol Metab 2000, 85(11):3990-3993.

26. Greulich WW, Pyle SI: Radiographic atlas of skeletal development of the hand and wrist. 2 edition. Stanford, Calif: Stanford University Press; 1959.

27. Rockett HR, Wolf AM, Colditz GA: Development and reproducibility of a food frequency questionnaire to assess diets of older children and adolescents. J Am Diet Assoc 1995, 95(3):336-340.

28. Rockett HR, Breitenbach M, Frazier AL, Witschi J, Wolf AM, Field AE, Colditz GA: Validation of a youth/adolescent food frequency questionnaire. Prev Med 1997, 26(6):808-816.

29. Aaron DJ, Kriska AM, Dearwater SR, Cauley JA, Metz KF, LaPorte RE: Reproducibility and validity of an epidemiologic questionnaire to assess past year physical activity in adolescents. Am J Epidemiol 1995, 142(2):191-201.

30. Baim S, Leonard MB, Bianchi ML, Hans DB, Kalkwarf HJ, Langman CB, Rauch F: Official Positions of the International Society for Clinical Densitometry and executive summary of the 2007 ISCD Pediatric Position Development Conference. J Clin Densitom 2008, 11(1):6-21.

31. Kelly J, Damron T, Grant W, Anker C, Holdridge S, Shaw S, Horton J, Cherrick I, Spadaro J: Cross-sectional study of bone mineral density in adult survivors of solid pediatric cancers. J Pediatr Hematol Oncol 2005, 27(5):248-253.

32. Kaste SC, Rai SN, Fleming K, McCammon EA, Tylavsky FA, Danish RK, Rose SR, Sitter CD, Pui CH, Hudson MM: Changes in bone mineral density in survivors of childhood acute lymphoblastic leukemia. Pediatr Blood Cancer 2006, 46(1):77-87.

33. Goulding A, Jones IE, Taylor RW, Manning PJ, Williams SM: More broken bones: a 4-year double cohort study of young girls with and without distal forearm fractures. J Bone Miner Res 2000, 15(10):2011-2018. 
34. Clark EM, Ness AR, Bishop NJ, Tobias JH: Association between bone mass and fractures in children: a prospective cohort study. J Bone Miner Res 2006, 21(9):1489-1495.

35. Hastie T, Tibshirani R: Generalized additive models London; New York: Chapman and Hall; 1990.

36. Ferrari SL, Chevalley T, Bonjour JP, Rizzoli R: Childhood fractures are associated with decreased bone mass gain during puberty: an early marker of persistent bone fragility? J Bone Miner Res 2006, 21(4):501-507.

37. Schoenau E: From mechanostat theory to development of the "Functional Muscle-Bone-Unit". J Musculoskelet Neuronal Interact 2005, 5(3):232-238.

38. Heinonen A, McKay HA, Whittall KP, Forster BB, Khan KM: Muscle crosssectional area is associated with specific site of bone in prepubertal girls: a quantitative magnetic resonance imaging study. Bone 2001, 29(4):388-392.

39. Schoenau E: The "functional muscle-bone unit": a two-step diagnostic algorithm in pediatric bone disease. Pediatr Nephrol 2005, 20(3):356-359.

40. Schoenau E, Neu CM, Mokov E, Wassmer G, Manz F: Influence of puberty on muscle area and cortical bone area of the forearm in boys and girls. J Clin Endocrinol Metab 2000, 85(3):1095-1098.

41. McKay HA, Petit MA, Khan KM, Schutz RW: Lifestyle determinants of bone mineral: a comparison between prepubertal Asian- and CaucasianCanadian boys and girls. Calcif Tissue Int 2000, 66(5):320-324.

42. Ma H, Leskinen T, Alen M, Cheng S, Sipila S, Heinonen A, Kaprio J, Suominen $H$, Kujala UM: Long-term leisure time physical activity and properties of bone: a twin study. J Bone Miner Res 2009, 24(8):1427-1433.

43. MacKelvie KJ, Khan KM, Petit MA, Janssen PA, McKay HA: A school-based exercise intervention elicits substantial bone health benefits: a 2-year randomized controlled trial in girls. Pediatrics 2003, 112(6 Pt 1):e447.

44. van der Sluis IM, van den Heuvel-Eibrink MM, Hahlen K, Krenning EP, de Muinck Keizer-Schrama SM: Bone mineral density, body composition, and height in long-term survivors of acute lymphoblastic leukemia in childhood. Med Pediatr Oncol 2000, 35(4):415-420.

45. Serrano-Sanchez JA, Marti-Trujillo S, Lera-Navarro A, Dorado-Garcia C, Gonzalez-Henriquez JJ, Sanchis-Moysi J: Associations between screen time and physical activity among Spanish adolescents. PLoS One 2011, 6(9): e24453.

46. Tamura T, Udagawa N, Takahashi N, Miyaura C, Tanaka S, Yamada Y, Koishihara Y, Ohsugi Y, Kumaki K, Taga T, et al: Soluble interleukin-6 receptor triggers osteoclast formation by interleukin 6. Proc Natl Acad Sci USA 1993, 90(24):11924-11928.

47. Palmqvist $P$, Persson $E$, Conaway $H H$, Lerner $U H$ : IL-6, leukemia inhibitory factor, and oncostatin $\mathrm{M}$ stimulate bone resorption and regulate the expression of receptor activator of NF-kappa B ligand, osteoprotegerin, and receptor activator of NF-kappa B in mouse calvariae. J Immunol 2002, 169(6):3353-3362.

48. De Benedetti F, Rucci N, Del Fattore A, Peruzzi B, Paro R, Longo M, Vivarelli M, Muratori F, Berni S, Ballanti P, et al: Impaired skeletal development in interleukin-6-transgenic mice: a model for the impact of chronic inflammation on the growing skeletal system. Arthritis Rheum 2006, 54(11):3551-3563

49. Scheidt-Nave C, Bismar H, Leidig-Bruckner G, Woitge H, Seibel MJ, Ziegler R, Pfeilschifter J: Serum interleukin 6 is a major predictor of bone loss in women specific to the first decade past menopause. J Clin Endocrinol Metab 2001, 86(5):2032-2042.

50. Papadopoulos NG, Georganas K, Skoutellas V, Konstantellos E, Lyritis GP: Correlation of interleukin- 6 serum levels with bone density in postmenopausal women. Clin Rheumatol 1997, 16(2):162-165.

51. Abrahamsen B, Bonnevie-Nielsen V, Ebbesen EN, Gram J, Beck-Nielsen H: Cytokines and bone loss in a 5-year longitudinal study-hormone replacement therapy suppresses serum soluble interleukin-6 receptor and increases interleukin-1-receptor antagonist: the Danish Osteoporosis Prevention Study. J Bone Miner Res 2000, 15(8):1545-1554.

52. Ding C, Parameswaran V, Udayan R, Burgess J, Jones G: Circulating levels of inflammatory markers predict change in bone mineral density and resorption in older adults: a longitudinal study. J Clin Endocrinol Metab 2008, 93(5):1952-1958.

53. Verbruggen A, De Clerck LS, Bridts CH, Van Offel JF, Stevens WJ: Flow cytometrical determination of interleukin 1beta, interleukin 6 and tumour necrosis factor alpha in monocytes of rheumatoid arthritis patients; relation with parameters of osteoporosis. Cytokine 1999, 11(11):869-874.

54. Pollak RD, Karmeli F, Eliakim R, Ackerman Z, Tabb K, Rachmilewitz D: Femoral neck osteopenia in patients with inflammatory bowel disease. Am J Gastroenterol 1998, 93(9):1483-1490.

55. Withold W, Wolf HH, Kollbach S, Heyll A, Schneider W, Reinauer H: Relationship between bone metabolism and plasma cytokine levels in patients at risk of post-transplantation bone disease after bone marrow transplantation. Eur J Clin Chem Clin Biochem 1996, 34(4):295-299.

56. Tauchmanova L, Colao A, Lombardi G, Rotoli B, Selleri C: Bone loss and its management in long-term survivors from allogeneic stem cell transplantation. J Clin Endocrinol Metab 2007, 92(12):4536-4545.

57. Lee WY, Cho SW, Oh ES, Oh KW, Lee JM, Yoon KH, Kang MI, Cha BY, Lee KW, Son HY, et al: The effect of bone marrow transplantation on the osteoblastic differentiation of human bone marrow stromal cells. J Clin Endocrinol Metab 2002, 87(1):329-335.

58. Lee WY, Baek KH, Rhee EJ, Tae HJ, Oh KW, Kang MI, Lee KW, Kim SW, Kim CC, Oh ES: Impact of circulating bone-resorbing cytokines on the subsequent bone loss following bone marrow transplantation. Bone Marrow Transplant 2004, 34(1):89-94.

59. Baek KH, Lee WY, Oh KW, Kim HS, Han JH, Kang MI, Cha BY, Lee KW, Son HY, Kang SK, et al: Changes in the serum growth factors and osteoprotegerin after bone marrow transplantation: impact on bone and mineral metabolism. J Clin Endocrinol Metab 2004, 89(3):1246-1254.

60. Prentice A, Parsons TJ, Cole TJ: Uncritical use of bone mineral density in absorptiometry may lead to size-related artifacts in the identification of bone mineral determinants. Am J Clin Nutr 1994, 60(6):837-842.

61. Leonard MB, Shults J, Elliott DM, Stallings VA, Zemel BS: Interpretation of whole body dual energy $\mathrm{X}$-ray absorptiometry measures in children: comparison with peripheral quantitative computed tomography. Bone 2004, 34(6):1044-1052.

62. Leonard MB, Propert KJ, Zemel BS, Stallings VA, Feldman HI: Discrepancies in pediatric bone mineral density reference data: potential for misdiagnosis of osteopenia. J Pediatr 1999, 135(2 Pt 1):182-188.

63. Bachrach LK: Dual energy X-ray absorptiometry (DEXA) measurements of bone density and body composition: promise and pitfalls. J Pediatr Endocrinol Metab 2000, 13(Suppl 2):983-988.

\section{Pre-publication history}

The pre-publication history for this paper can be accessed here: http://www.biomedcentral.com/1471-2431/12/40/prepub

\section{doi:10.1186/1471-2431-12-40}

Cite this article as: Polgreen et al:: Modifiable risk factors associated with bone deficits in childhood cancer survivors. BMC Pediatrics 2012 12:40.

\section{Submit your next manuscript to BioMed Central and take full advantage of:}

- Convenient online submission

- Thorough peer review

- No space constraints or color figure charges

- Immediate publication on acceptance

- Inclusion in PubMed, CAS, Scopus and Google Scholar

- Research which is freely available for redistribution

Submit your manuscript at www.biomedcentral.com/submit
C Biomed Central 